\title{
DREDGING OF CONTAMINATED SEDIMENTS IN THE WESER ESTUARY: CHEMICAL FORMS OF SOME HEAVY METALS
}

\author{
W. Calmano* and S. Wellershaus \\ Institut für Meeresforschung. D-2850 Bremerhaven, F.R. Germany \\ U. Förstner \\ Arbeitsbereich Unweltschutztechnik, Technische Universität Hamburg-Harburg \\ 2100 Hamburg 90, F.R. Germany
}

(Received 18 March 1982; in final form 2 April 1982)

\begin{abstract}
Concentration and chemical forms of metals in bottom sediments and dredged mud of the Weser Estuary were studied. The sediments with the highest metal contents are found in the harbour basins of Bremen and in the mud shoal near Nordenham. Association types of the metals can be divided into 2 groups: metals with relatively high potential of mobilization, such as $\mathrm{Cd}, \mathrm{Zn}, \mathrm{Mn}$, and $\mathrm{Ni}$ and those that are strongly bound on particles - $\mathrm{Cr}, \mathrm{Cu}, \mathrm{Pb}$ and $\mathrm{Fe}$. An estimation of the bioavailability of these metals based on chemical extraction studies is relevant to problems encountered during disposal of dredged materials.
\end{abstract}

\section{INTRODUCTION}

According to information provided by the Federal Institute of Hydrology in Koblenz approximately $30 \mathrm{million} \mathrm{m}^{3}$ dredged sludge are produced during maintenace dredging cach year in the coastal regions of the Federal Republic of Germany. Maintenance dredging is regularly undertaken in the mud shoal (1) of the estuary of the weser and other rivers as a measure to clear and maintain shipping channels. Dredged sludge is quantitatively the largest portion of waste products dumped into the North Sea; in 197872 million tons of dredged sludges were dumped into the area covered by the oslo convention. The amount which the Federal Republic of Germany disposed into its immediate territorial waters was $12 \mathrm{million} \mathrm{m}^{3}$ in 1977 and $2.5 \mathrm{million} \mathrm{m}^{3}$ in 1978 (2). The greatest portion of the weser maintenance dredging sludge is dumped near lower Weser River kilometer 80 (UW-km 80$)$. It is not clear to what extent this material is then washed into the North sea or re-transported into the mud zone.

The Weser sediments - and consequently the dredged sludge - are contaminated with municipal, industrial and agricultural wastes and runoff. This contamination consists of potentially significant amounts of chemical toxicants and heavy metals. It is conceivable that under certain conditions the contaminants present in these sediments could have an adverse effect on the environmental quality at both the dredging and disposal sites (3).

In order to estimate the potential effects of metal contaminated sediments or aredged sludges on biota, those metallic association types that may be participants in the short- or middle-term chemical and physiological processes must be investigated. Furthermore, an environmental compatability test must take into account the various remobilization effects that may play a role in certain parameters such as increased salt concentrations in estuaries and disposal sites in the ocean, alteration of the oxygen contents, the reduction of $\mathrm{pH}$ values due to acid precipitation, and increased concentrations of organic complexing agents (4). Therefore, extraction sequences have 
been developed for heavy metals and phosphorus from which the relative association strength and environmental behaviour of these components in the solid phase can be estimated $(5,6)$.

\section{THE ENVIRONMENT}

Hydrographic and sedimentologic descriptions of the coastal plain estuary of the Weser are given by Lüneburg et al. (7) and Wellershaus (1). Like other dredged estuaries the weser is characterized by a mud shoal and a turbidity maximum in the zone where 5 to $15^{\circ}$ isohalines intersect with the bottom. Further upstream and downstream the sediments consist of sand except some sheltered places in harbour basins and calm bays.

Due to complicated processes the mud and suspended material (seston) are roughly identical - at least in the $<63 \mu \mathrm{m}$ fraction.

Mud as well as seston contain minerals and organic matter. During its bacterial decomposition oxygen depletion takes place in the near-bottom water, and reducing conditions are common in the sediments a few centimeters below its surface.

\section{METHODS AND MATERIALS}

\section{arming}

Jirint 1980 and 1981 samples of innt and dredged material were arr. "rre the weser Estuary in order $\because$ irtrominr the contents of heavy "..t it 13 , shophorus and organic substanr:: as wl as the chemical forms of the hra\% motal 3 and phosphorus. The results for rhosphorus and the organic substances have al ready been reported $(6,5)$.

Sampling in thr weser River Estuary was carried out from the research vessel VICTOR HENSEN and from the hopner suction dredger LUDWIG FRANZIU: on several sampling trips. Figure 1 shows a general view of the estuary with the various sampling stations beginning in river water and ending at higher salinities.

The following trips and tasks were carried out:

16. May 1980: Sediment sampling from the middle of the dredged shipping channel at spring tide;

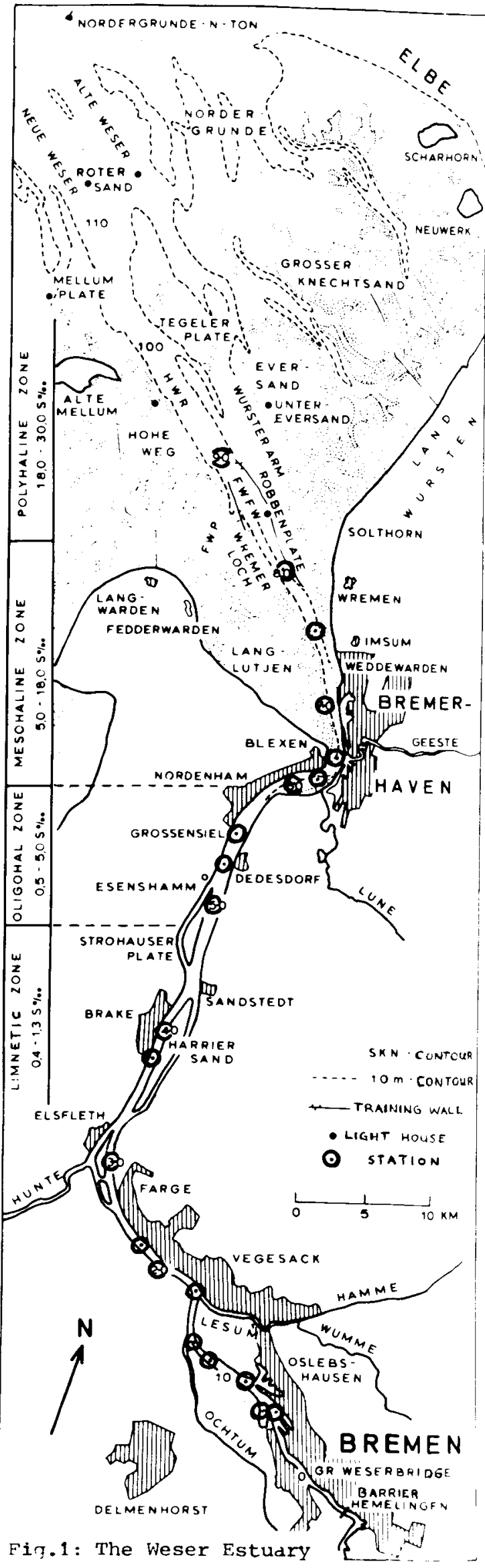


3. October 1980: Dredged sludge from on board the hopper suction dredger at the inflow and outflow of the mud containing spaces, taken from the mud shoal near Nordenham (UW-km 55);

16. March 1981: Sediments from the harbours of Bremen, from the middle of the shipping channel as well as from the eastern and western slopes at neap tide;

13. July 1981: Dredged sludge on board the hopper suction dredger as well as se-

diments from the disposal site.

Sediment sampling was done with a Van-Veen grab. Two or three samples were taken at each station and the material thus obtained was deep frozen for subseruent analysis.

Analysis of samples

The sediments and dredged sludge were freeze dried and the particle fraction $<63 \mu \mathrm{m}$ was separated. It was in this fraction (silt and clay) that the areatest amount of heavy metals was found. There was no grain fractionation of the dredged sludge samples taken on October, 1980.

The samples were digested with concentrated $\mathrm{HNO}_{3}$ for two hours at $180^{\circ} \mathrm{C}$. With this procedure all heavy metals with the exception of Fe and Ni were nearly completely solubilized. Analysis was made using flame- and carbon furnace atomic absorption spectroscopy for the metals $\mathrm{Cd}, \mathrm{Cr}, \mathrm{Cu}, \mathrm{Fe}, \mathrm{Mn}, \mathrm{N} j, \mathrm{~Pb}$, and $\mathrm{Zn}$. The accuracy of analysis was tested with a sediment standard. The Fe and $\mathrm{Ni}$ values had to be corrected by the factor 1.7 and 1.4 , respectively, due to incomplete dissolution with the $\mathrm{HNO}_{3}$ reagent.

RESULTS

Metals in sediments

The results are presented in Table 2 and Figure 2. The sediments with the highest metal contents were found in the harbour basins of Bremen and up to UW-km 20 , after which they decreased in a constant manner, but began to increase again near Uw$\mathrm{km}$ 50-70. In this segment of the mud shoal, the shipping channel is constantly dredged. Especially high metal contents were found in the upper layer of a sediment core $(\mathrm{O}-2 \mathrm{~cm})$ at $\mathrm{UW}-\mathrm{km} 60$, which was taken from the west bank immediately in front of a lead, zinc and cadmium processing facility. The metal contents sank once more further downstream in the estuary.

Metals in dredged materials

The metal contents of the samples of dredged materials investigated did not significantly differ from those of the sediments because the material was chiefly finely grained with a negligible sand portion. For comparison, Table 1 shows two samples for which no grain fractionation was carried out and one sample for which only the fraction $<63 \mu \mathrm{m}$ was investigated. All three samples originate from the mud shoal zone between UW-km 50-60.

\begin{tabular}{|c|c|c|c|c|c|c|c|}
\hline Sample & $\mathrm{Cd}$ & $\mathrm{Cr}$ & $\mathrm{Cu}$ & $\mathrm{Fe}$ & $\mathrm{Mn}$ & $\mathrm{Ni}$ & $\mathrm{Pb}$ \\
\hline
\end{tabular}

no grain fractionation $(10 / 3 / 80)$

\begin{tabular}{rrrrrrrrr} 
dredger-inflow & 2.71 & 37.4 & 23.4 & 23802 & 1185 & 24.6 & 6.7 & 272 \\
dredger-outflow & 2.49 & 34.5 & 25.5 & 22240 & 1219 & 23.2 & 61.7 & 282 \\
\hline fraction $63 \mu \mathrm{m}$ & $(7 / 13 / 81)$ \\
& 3.30 & 61.6 & 26.1 & 25800 & 1440 & 39.0 & 56.6 & 280
\end{tabular}

Table 1 : Metal contents in dredged material 


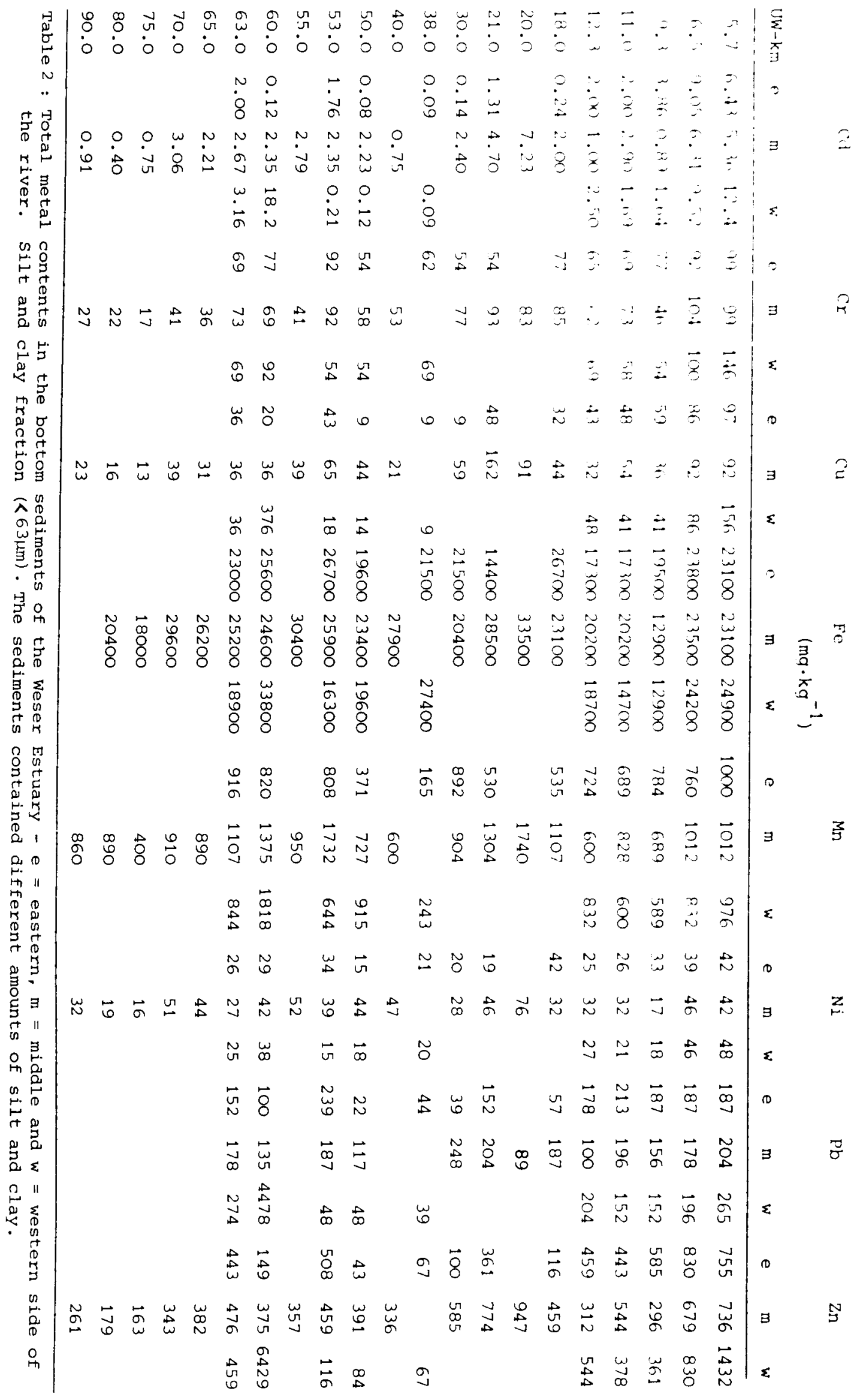



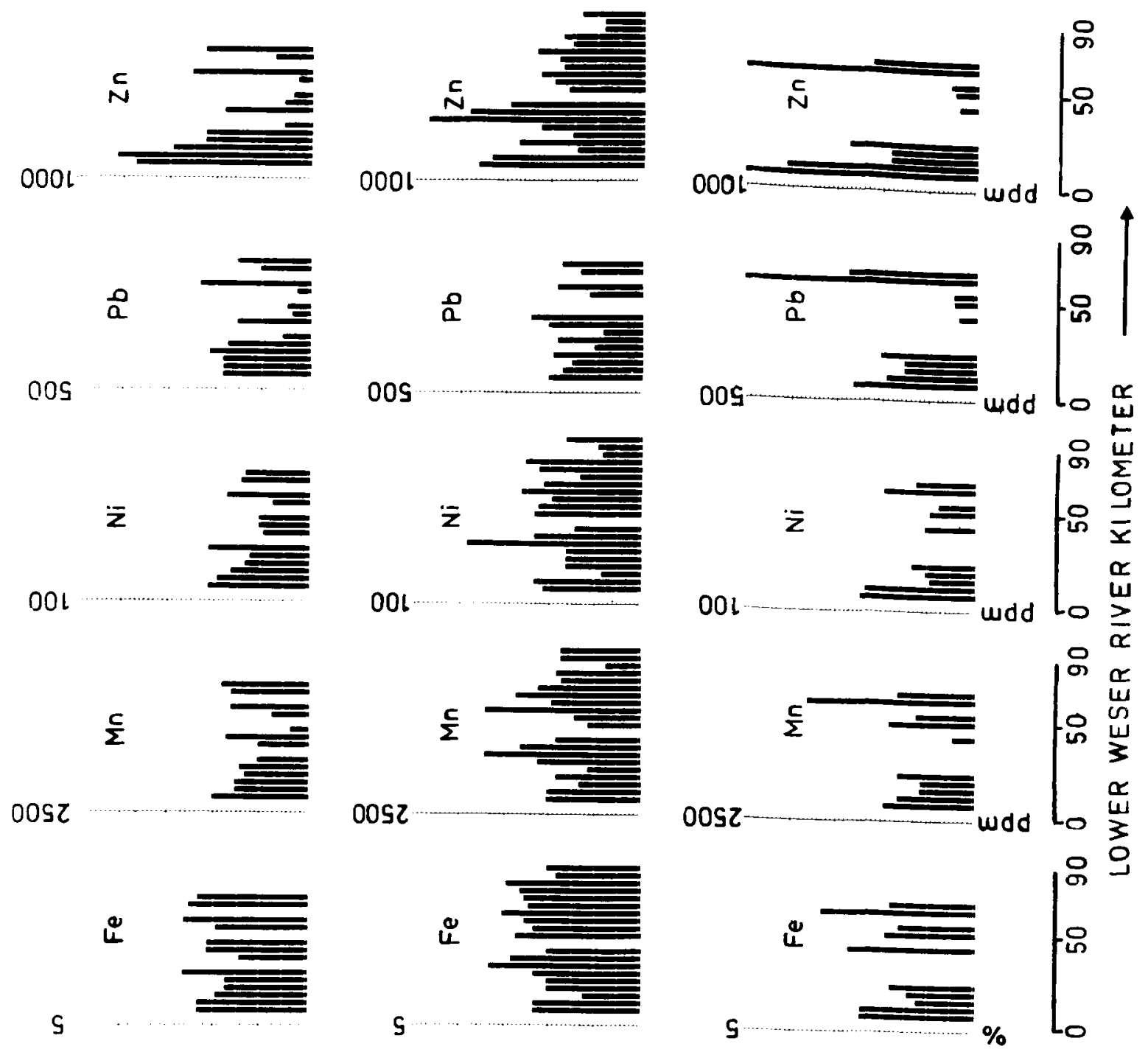

oosz

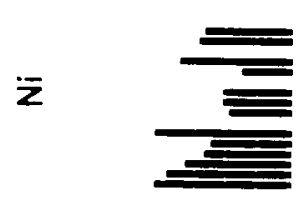

001
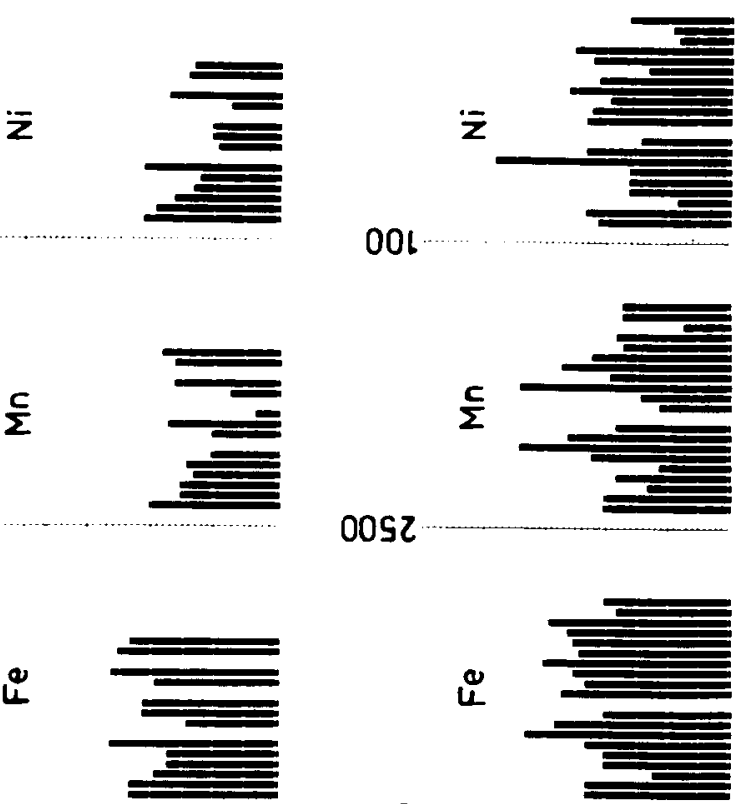

s

S
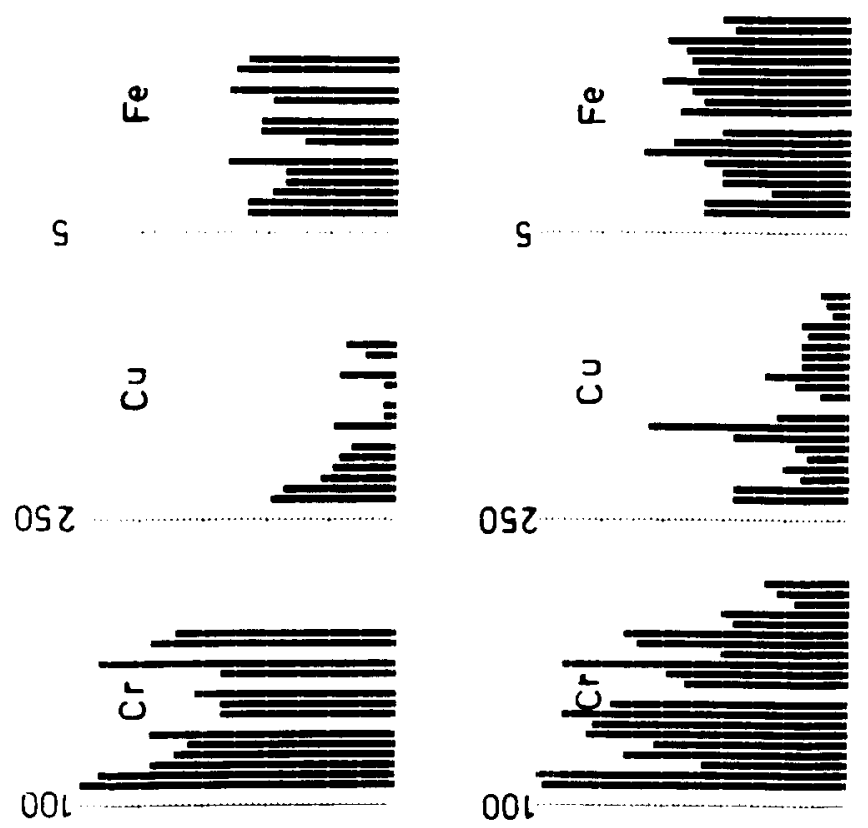

os2
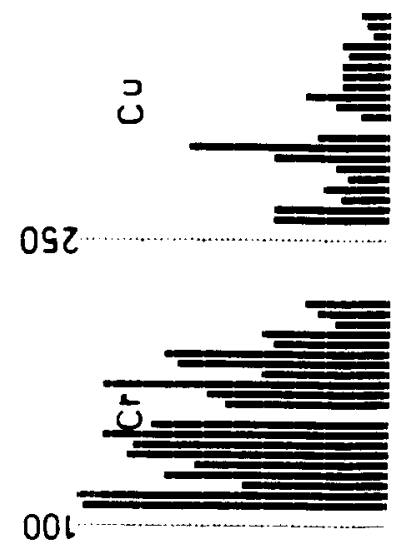

092
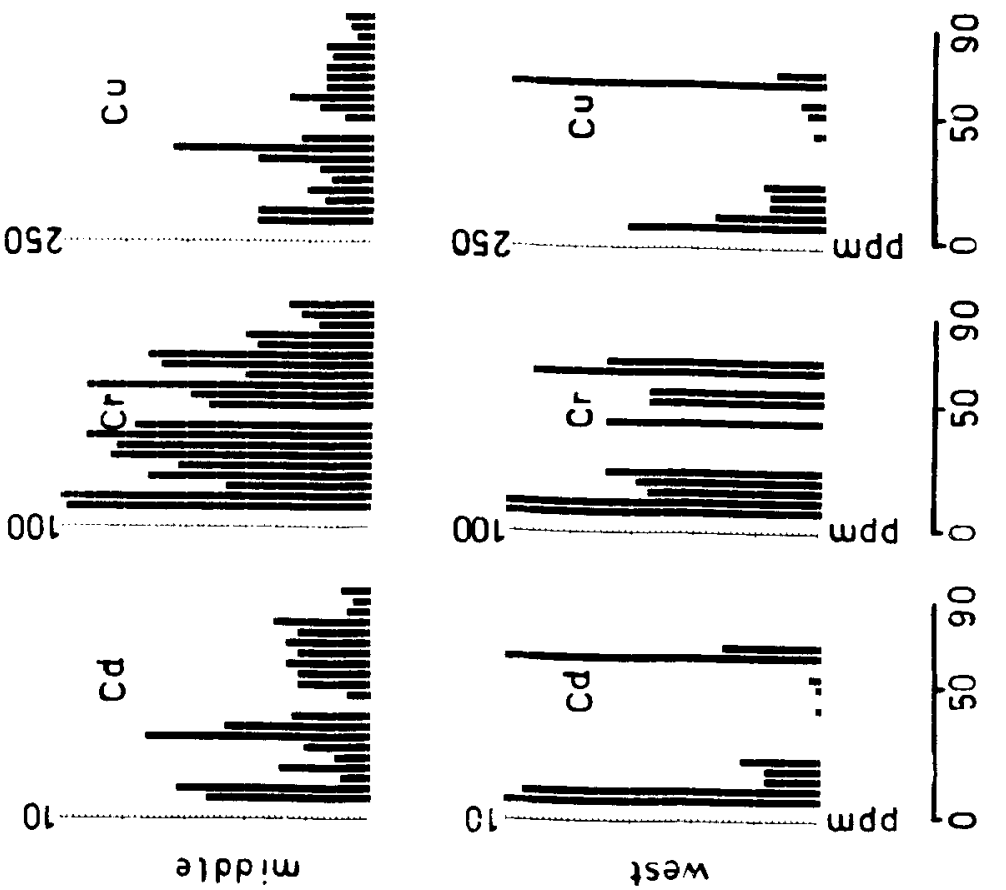

ISOM 
Following a review of varıous procedures given in the literature, Salomons \& Förstner (5) propose a standard extraction method for the assessment of the association form of particle-associated heavy metals. Three solid phases can be distinguished:

1. Exchangeable cations, manganese compounds and carbonate-bound metals;

2. Metals bound to organics and sulfides;

3. Metals bound in crystal lattices of detrital silicates.

This standard extraction scheme is still somewhat unsatisfactory later on in the sequence. The moderately reducible components are partially extracted with $\mathrm{H}_{2} \mathrm{O}_{2}$ ' but a portion of this fraction, which may well originate to a certain extent ${ }^{2} \mathrm{f}^{2} \mathrm{~m}$ anthropogenic sources, is not extracted by the suggested reagents.

As to the question of biotic availability, this aspect could very well be of secondary importance, concerning as it does relatively stably bound metal phases. It appears, however, that for other fields of application, for example the determination of origin and distribution as well as diagenetic effects, it is important to have an additional extraction step for moderately reducible components.

After consideration of the above facts, we introduced the application of the Schwertmann oxalate buffer reagent (9) directly after leaching with acidified hydroxylamine hydrochloride. While maintaining as good a practicability as possible, we applied the following scheme (10):

I Exchangeable cations - $1 \mathrm{M}$ ammonium acetate, pH 7, solid/solution ratio 1:20, 2 h shaking;

II Easily reducible phases (Mn-oxides, partly amorphous Fe-oxyhydrates and carbonate phases) - $0.1 \mathrm{M} \mathrm{NH} \mathrm{OH} \mathrm{HCl}, \mathrm{pH} 2$, dilution $1: 100,12 \mathrm{~h}$ shaking;

II Moderately reducible phases (e.g. amorphous and poorly crystallized Fe-oxyhydrates) - $0.2 \mathrm{M}$ ammonium oxalate $+0.2 \mathrm{M}$ oxalic acid, pH 3, dilution 1:100, $24 \mathrm{~h}$ shaking;

IV Organic fraction, incl. sulfides - 30\% $\mathrm{H}_{2} \mathrm{O}_{2}, 85^{\circ} \mathrm{C}$, extracted with $1 \mathrm{M}$ ammonium acetate, dilution $1: 100,12 \mathrm{~h}$ shaking;

$\mathrm{V}$ Residual fraction - conc. $\mathrm{HNO}_{3}, 180^{\circ} \mathrm{C}$, dilution $1: 100$.

Figure 3 includes data from the extraction experiments on selected samples of bottom sediment from the estuarine zone and on two dredged sludge samples.

Principally, two categories can be distinguished:

- metals, such as $\mathrm{Cd}, \mathrm{Zn}, \mathrm{Mn}$ and $\mathrm{Ni}$ that have a relatively large potential mobilizable portion, and

- metals, such as $\mathrm{Cr}, \mathrm{Cu}, \mathrm{Pb}$ and $\mathrm{Fe}$ that are stably bound on sediment particles.

It is apparent that 5-20\% copper is found in the organic/sulfidic fraction. To which extent metals from this fraction are released, e.g. by microbic transformation of organic material, is unclear.

$\mathrm{Cd}$ and $\mathrm{Zn}$ show very similar association behaviour. They are found mostly in the easily reducible and exchangeable phases, from which they, like Mn, can be released under anaerobic conditions.

A comparison of sediments and dredged materials does not indicate any difference in the type of association of the individual metals. A deviation from this pattern, however, is the heavily contaminated sediment sample from UW-km 60 . In it the mineralic and sulfidic components are predominant for the elements $\mathrm{Pb}, \mathrm{Cd}, \mathrm{Zn}$ and $\mathrm{Cu}$. It is this fact and the lead contents 20 times greater than average that point to the presence of ore muds or ore dust that would originate from the nearby lead works. 

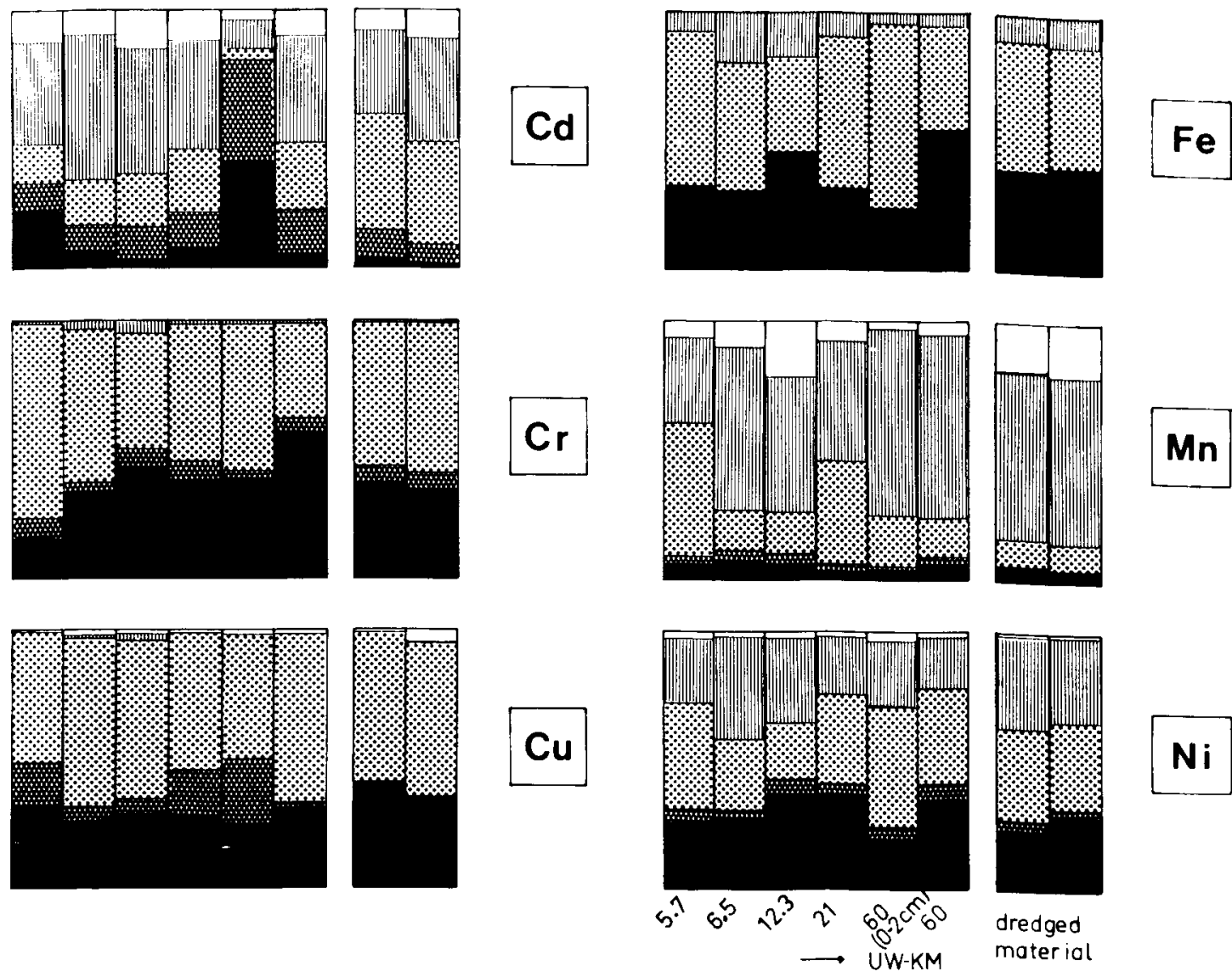

$\mathbf{N i}$
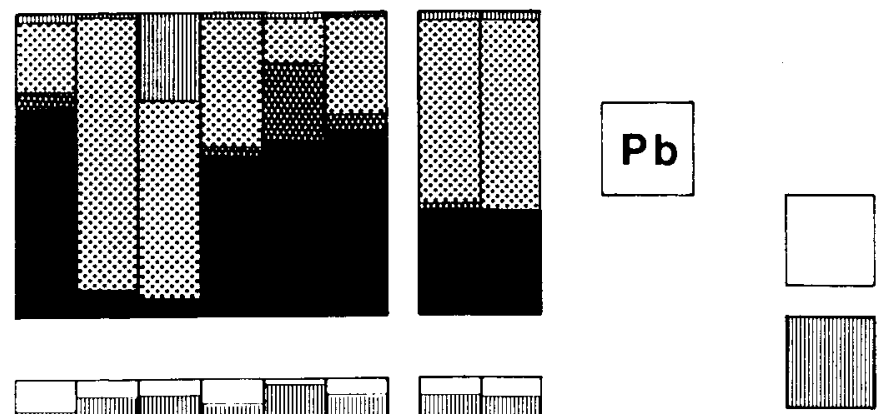

exchangeable cations
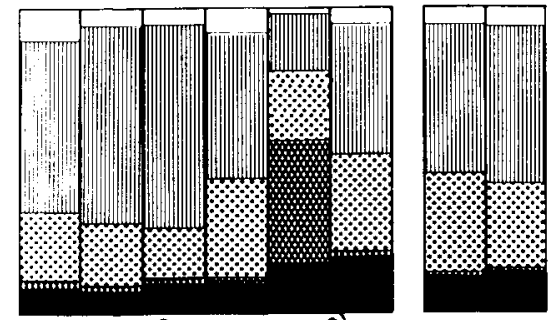

easily reducible fraction

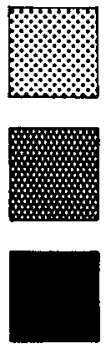
moderately reducible fraction organic / sulfidic fraction residual fraction

id. 3: Speciation of heavy metals in bottom sediments and drforod sludge ifrom UW-km 55: of the Weser Estuary 
Dredging during 1981 in the weser Estuary produced 8 million $\mathrm{m}^{3}$ of material including 5 million $\mathrm{m}^{3}$ mud, most of which was subsequently dumped into the outer estuary at Weser $-\mathrm{km} 81$ (11). From the average metal contents of the sediments in the dredging zone (UW-km 51-65) the quantity of heavy metals moved can be determined if it is taken into account that the dredged silty sludge consists of $20 \%$ solid materials. Table 3 shows total values and the anthropogenic portion of heavy metals dredged in the mud zone in 1981.

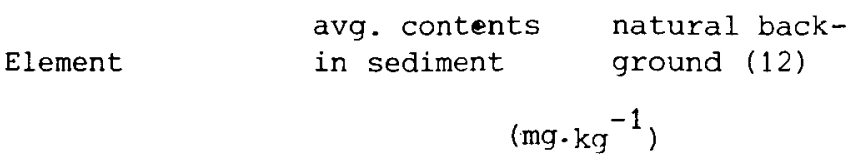
total anthropogenic portion in dredged mud

(tonnes, 1981)

\begin{tabular}{lrrrr}
\hline $\mathrm{Cd}$ & 2.4 & 0.2 & 6 & 5.5 \\
$\mathrm{Cr}$ & 62 & 60 & 155 & 5 \\
$\mathrm{Cu}$ & 42 & 31 & 105 & 27 \\
$\mathrm{Ni}$ & 58 & 32 & 145 & 65 \\
$\mathrm{~Pb}$ & 154 & 20 & 385 & 335 \\
$\mathrm{Zn}$ & 393 & 95 & 983 & 745 \\
\hline
\end{tabular}

Table 3: Amount of heavy metals dredged in the mud zone of the Weser Estuary in 1981

There are several possible fates for the disposed sludges:

- they are removed from the estuarine zone completely and washed into the North Sca, - or they are washed onto the tidal mud flats,

- or they are transported back into the dredged zone by "bottom density curronts" ( 1 ). The final fate can only be determined by hydrological investigations.

We were mainly interested in the physico-chemical behaviour of the heavy metals associated with the sediments. During dredging, oxygen content does not romain stable in the sediment. When the sludge is dumped at sea, it is gonerally introduced into an environment that has a higher oxygen and salt content.

With regard to oxidizing conditions chen et al. (13) have found that all metals; observed, with the exception of $\mathrm{Cr}$, were released in the sediment-water interface. In comparison with background seawater they found that $\mathrm{Cd}, \mathrm{Mn}, \mathrm{Ni}$ and $\mathrm{Zn}$ were significantly released; $\mathrm{Cu}, \mathrm{Fe}$ and $\mathrm{Pb}$ were only moderately released. It is suggested that the release effect is mainly the result of carbonate and the formation of chloro- and organo-complexes. Under reducing conditions, Fe and Mn were mobilized to a very high level (ppm range). The concentration of the other dissolved metals decreased to extremely low values in the initial contact period. With time the concentrations of $\mathrm{Cd}, \mathrm{Cu}, \mathrm{Ni}, \mathrm{Pb}$ and $\mathrm{Zn}$ increased once more. The decrease effect is a result of metallic sulfide formation. The redissolution effect is due to the desorption from $F e$ and $M n$ or clay minerals and the slow kinetics of the metajsulfide precipitation, the formation of sulfide complexes, or the formation of organo-metallic complexes. 
We investigated dissolution rates of the metals in artifical seawater in a relatively short period, namely $96 \mathrm{~h}$. Results showed that Mn was siqnificantly released (25\%), $\mathrm{Pb}, \mathrm{Cd}$ and $\mathrm{Zn}$ were released to only a very small extent and that for other metals no dissolution effects were observed.

Due to the extremely low concentrations of metals in seawater, the relative factors of release over the background levels should not be used as dredging criteria. The release of metals in the soluble phase is deemed ecologically insignificant (13). During a dumping event, we observed the behaviour of metals sorbed to the dredged sludge; there was no measurable increase in the heavy metal concentration in solution. However, metals associated with certain fractions of the dredged sediments, e.g. with the organic phase or the interstitial waters, might be available as a food source for filter-feeders and algae, and will possibly present some potential problems.

This is even more true for disposal of dredged materials on land. The suggested extraction sequence can here too give indication of potential mobilization processes.

The extraction mechanisms with which plant roots actively participate in the removing of nutrients from soil include redox-and pH-alteration $(14,15)$ and the organic complexing processes (16). From the simulation of these basic mechanisms - which could vary greatly to plant or soil type and climatic conditions - it is possible to arrive at conclusions as to the biological availability.

For complexing processes from soil, the DTPA reagent introduced by Lindsay \& Norwell (17) appears to be a good indicator of the reservoir of labile metal compounds. Its disadvantage lies in its poor phase specifity.

In the present extraction sequence the treatment with ammonium acetate gives the easiest available fraction. The subsequent hydroxylamine treatment includes those metal portions occluded in a Mn-oxide matrix that may be released during post-oxic changes in the sediment. In the third stage (oxalate buffer), the simulated dissolution of Fe-compounds in comparison may amount to a relatively small portion during normal metabolic processes.

The uptake of metals in aquatic environments and by terrestrial plants is not a single function of total metal concentration. The prediction of the toxicity on organisms requires the understanding of the physical, chemical and biotic processes, which uncouple uptake from total concentration and control the biological availability of metals. Future investigations should concentrate on the development of bioindicator procedures.

\section{ACKNOWLEEDGEMENT}

We express our gratitude to $\mathrm{Mr}$. Lange of the Wasser- und Schiffahrtsamt, Bremerhaven and to the crews of the VICTOR HENSEN and LUDWIG FRANZIUS for their kind help during sampling. We also thank D. Godfrey who aided in the preparation of the English version of the manuscript. We received welcome support from the BMFT (German Ministry of Research and Technology). 
$\therefore$ S. Wellershaus, Arch. Hydrobiol., 92, 161-198 (1981)

2. Rat der Sachverständigen für Umweltfragen, Umweltprobleme der Nordsee. Stuttgart (1979)

3. G.F. Lee, R.H. Plumb, U.S. Army Eng. Waterways Experiment Station, Vicksburg/Miss., Contract Report D-74-1 (1974)

4. U. Förstner, Chemiker-Zeitung, 105, 165-174 (1981)

5. W. Salomons, U. Förstner, Environ. Technol. Letts., 1 (11), 506-517 (1980)

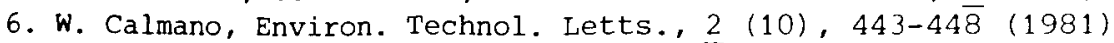

7. H. Lüneburg et al., veröff. Inst. Meeresforsch. Bremerh., 15, 195-226 (1975)

8. S. Wellershaus, Environ. Technol. Letts., 2 (4), 153-160 (1981)

9. U. Schwertmann, Z. Pflanzenernähr. Düngem. Bodenkd., 105, 194-202 (1964)

10. U. Förstner et al., Proc. Int. Conf. "Heavy Metals in the Environment", Amsterdam, Sept. 1981

11. Wasser- und Schiffahrtsamt, Bremerhaven, priv. comm.

12. K.H. Wedepohl (Hrsg.), Handbook of Geochemistry, Springer Verlag, Berlin 1969-19

13. K.Y. Chen et al., U.S. Army Eng. Waterways Experiment Station, Vicksburg/Miss., Contract Report D-76-1 (1976)

14. R.L. Chaney, J.C. Brown and L.O. Tiffin, Plant Physiol., 50, 208-221 (1972)

15. D.P. Moore, in E.W. Carson Ed.), The Plant Root and its Environment, Ch. 6 , University Press of Virginia, Charlottesville, pp. 135-151 (1974)

16. W.L. Lindsay, ibid, Ch. 17, pp. 507-524

17. W.L. Lindsay, W.A. Norwe11, Agron. Abstr. Amer. Soc. Agron., p. 84 (1969) 